- encroaching darkness of the high northern winter will limit their usefulness, says Sara Barsotti, an atmospheric physicist at the Icelandic Meteorological Office. (Even getting to the eruption site, which is remote, is getting harder as the winter sets in.) Researchers will try to continue making as many gas measurements on the ground as possible, and compare those to the rough estimates made by satellites, Barsotti says.

Icelandic officials are trying to work out how much of a hazard the sulphur is and whether they can predict its movement more accurately. The meteorological office has begun issuing forecasts of where the gas is likely to travel each day. Sulphur spikes as high as 21,000 micrograms per cubic metre were measured last weekend in the town of Höfn; the World Health Organization recommends no more than 500 micrograms per cubic metre for a 10-minute exposure.

No one has died in the eruption, and the plume is not high enough to penetrate the stratosphere and cause widespread climate perturbations. But the million tonnes of sulphur emitted so far are an unprecedented experiment in testing the effects of toxic-gas exposure, Barsotti says.

Lessons from Iceland may prove useful in understanding long-term gas exposure in other volcanic regions, such as Japan, Indonesia and Hawaii. In the early 2000s, residents around the Miyake-jima volcano in Japan were evacuated when it began erupting with roughly the same level of sulphur emissions.

In Iceland, the last similar event was a fissure eruption known as the Krafla fires that began in 1975 and lasted on and off until 1984, says Freysteinn Sigmundsson, a volcanologist at the University of Iceland and co-leader of FUTUREVOLC. If the current eruption is tapping magma deep in the crust, as the lava's volume and chemistry suggest, then it, too, may continue for months or even years.

"This eruption comes at aood time for the project," Sigmundsson says, waving out his office window at Reykjavik's red skies. "We don't see an end in sight." -

\title{
'Forgotten' NIH smallpox virus languishes on death row
}

\section{World Health Organization lacks resources to witness destruction of stocks.}

\section{BY SARA REARDON}

$\mathrm{S}$ ix vials of smallpox virus discovered at the US National Institutes of Health (NIH) in Bethesda, Maryland, in June are marked for death by autoclave - yet they linger in a high-security freezer. Chalk it up to bureaucracy: an international agreement requires that the World Health Organization (WHO) witnesses the destruction of the samples, but the agency is overwhelmed by the Ebola outbreak in West Africa.

The delay adds another twist to the strange tale of the vials, which sat forgotten for six decades in an unmarked cardboard box. It also mirrors the fierce debate over whether to destroy the two other known stocks of smallpox in the world. That decision is on hold while the WHO determines whether smallpox virus could be synthesized from scratch by those with nefarious intent, and whether virus stocks should therefore be preserved to help develop countermeasures against a terrorist attack.

The NIH smallpox was discovered in an agency 'cold room' used by the US Food and Drug Administration; soon after, the vials were shipped to the US Centers for Disease Control and Prevention (CDC) in Atlanta, Georgia. That agency, and its Russian counterpart VECTOR, in Koltsovo - are the only two laboratories authorized to work with smallpox under an international agreement that also calls for the eventual destruction of all stocks. (The

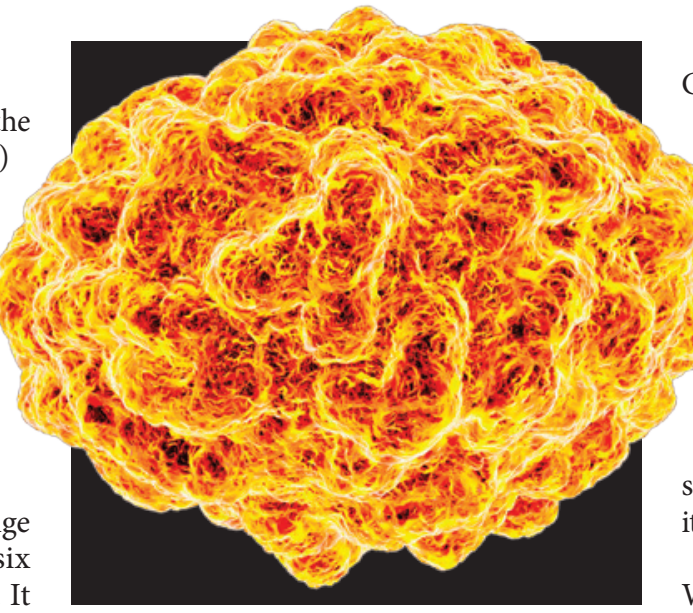

Research stocks of smallpox virus are limited.

virus was eradicated in the wild in 1979.)

The CDC promised to destroy the NIH samples immediately, with WHO officials present. But that has proved more difficult than anticipated. The WHO has dealt with just one other surprise smallpox discovery: viral DNA found in a South African laboratory in 2013. WHO officials were present when that DNA was destroyed in January this year - but no WHO employee is certified to enter the CDC's high-security smallpox lab. This means that a WHO official must fly to Atlanta to witness the destruction of the virus on closed-circuit television. Arranging the trip has been made more difficult by the Ebola crisis, says Alejandro Costa, head of the WHO team in Geneva, Switzerland, that monitors smallpox issues.
The authorized stocks of smallpox at the CDC and VECTOR are also in limbo. For more than 20 years, the US and Russian governments have fought efforts to set a deadline to destroy the samples. They argue that the virus should be preserved to test vaccines and antivirals that might be needed to respond to an accidental smallpox release or a terrorist attack.

In May, the WHO's policy-making body, the World Health Assembly, again put off a decision on the fate of the smallpox stocks. Unusually, the group did not say when it might revisit the issue.

Virologist D. A. Henderson, who led the WHO's programme to eradicate smallpox, argues that all stocks should be destroyed, in a kind of mutual disarmament. "Anyone found with isolates of smallpox virus after point $\mathrm{X}$ would be guilty of crimes against humanity," says Henderson, now at the Center for Health Security in Baltimore, Maryland.

At a meeting last week, members of the WHO Advisory Committee on Variola Virus Research discussed the risk that a bioterrorist could synthesize smallpox - a situation that might add weight to the argument for keeping the natural virus. Costa says that the WHO will postpone any decision on stock destruction until a report commissioned by the agency is released, which will be in 2016 at the earliest.

The NIH smallpox is likely to be destroyed well before then: Costa estimates by January 2015. In the meantime, experts say that the virus is safe at the CDC.. 